\section{Does Primed Seed Improve Stand Establishment and Yield of Broccoli?}

\author{
Lewis W. Jett ${ }^{1}$, Gregory E. \\ Welbaum², Charles R. O'Dell ${ }^{3}$, \\ and Ronald D. Morse
}

Additional index words. germination, emergence, yield, Brassica oleracea

Summary. The effect of matric and osmotic seed priming on stand establishment and maturity of broccoli (Brassica oleracea L. var. italica) was investigated in three years at two locations in Virginia. Seeds ('Earlidawn') were primed at $1.1 \mathrm{MPa}$ (68F for 7 days) either osmotically in polyethylene glycol (8000 molecular weight) or metrically in vermiculite (horticultural grade no. 2). In the frost year of the study, seeds were hand-seeded in August into crustprone soil with a mean temperature of $82 \mathrm{~F}$, and there were no differences in the percentage or mean time of seedling emergence between osmoticand matric-primed seeds. Under cooler temperatures during the remaining two years of the study, priming increased the percent emergence and decreased the mean time of emergence by about 15 hours. Primed seeds did not increase yields or accelerate maturity in two out of three years. In the third year, the spread of seedling emergence times was less for primed seeds, which reduced plant-toplant competition and hastened maturity. The primary benefit of primed broccoli seeds was faster emergence, which increased stands by reducing exposure to stresses that decrease emergence.

Deparment of Horticulture, VirginiaPolytechnic Institute and State University, Blacksburg, VA 24061-0327.

'Graduate research assistant.

${ }^{2}$ Assistant professor.

${ }^{3}$ Extension specialist, Vegetable Crops.

"Associate professor.

We are grateful Sakata Seeds America Inc., Morgan Hill, CA for supplying broccoli seeds. The cost of publishing this paper was defrayed in part by the payment of page charges. Under postal regulations tbis paper therefore must be hereby marked advertisement solely to indicate this fact.
S eed priming is a controlled hydration procedure followed by redrying that improves the germination performance of many horticultural seeds (Bradford, 1986; Khan, 1992). Primed seeds are available from many commercial seed companies. However, the word primed may not always appear on the label because the Federal Seed Act does not require special labeling for primed seeds (Copeland and McDonald, 1985). The benefits of priming have been well documented in a number of laboratory and field studies and include faster germination (Dahal et al., 1990), the removal of dormancy (Cantliffe et al., 1984; Wurr and Fellows, 1984), and improved stand establishment (Khan et al., 1992). In rapidly maturing crops grown for their vegetative tissues, the earlier emergence of primed seeds resulted in earlier maturity of carrots (Brocklehurst and Dearman, 1983; Szafirowska et al., 1981), onions (Brocklehurst and Dearman, 1983), and lettuce (Gray and Steckel, 1976). In contrast, the earlier emergence of primed seeds often does not translate into an earlier harvest for crops that are grown for their reproductive organs. The earliness of harvest for processing tomatoes was not hastened by priming even though priming decreased the mean time to emergence in the field (Alvarado et al., 1987). In another study with tomato, priming increased the percentage of red fruit at harvest by 10 to $12 \%$ (Wolfe and Sims, 1982). Primed watermelon seeds emerged more rapidly but generally did not produce greater early or total yield (Elmstrom, 1985).

Broccoli is grown for its immature flower buds, so it may be considered to be intermediate between crops grown for reproductive organs or for vegetative tissues. In the Southeastern United States, fall production of freshmarket, bunching broccoli is established by direct-seeding into clay soils during hot, humid conditions that can reduce seedling emergence and final stands (Elson et al., 1992; Jett and Welbaum, 1992).

Preliminary studies have shown that seed priming improved the percent emergence of broccoli seedlings (Jett and Welbaum, 1992). In this study, we investigated the performance of both matric and osmotic priming seed treatments on field emergence, mean time to harvest, and yield of field-grown broccoli under crusting soil conditions (Fig. 1 ) at two locations in Virginia.

\section{Materials and methods}

'Earlidawn' Broccoli seeds (Sakata Seeds America, Morgan Hill, Calif.) were osmotically primed in 10inch $^{2}$-square petri dishes on two thicknesses of germination blotter paper (Anchor Paper Co., St. Paul, Minn.)

Fig. 1. A broccoli field in Halifax County, Vs., where soil crusting has reduced the emergence of broccoli seedlings. Primed broccoli seeds germinate faster and emerged more uniformly than nonprimed seeds because seedlings emerged before crusting and other stresses reduced stands.

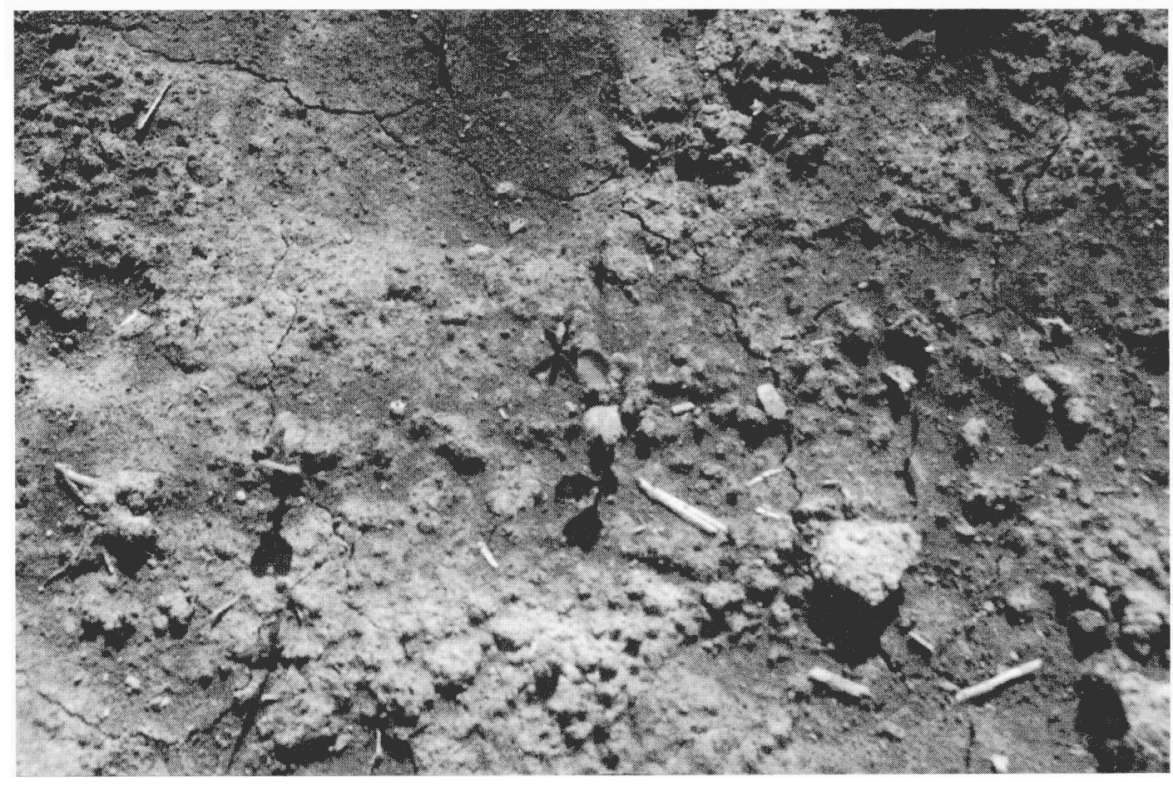


saturated (4.8 fluid oz/oz seed) with polyethylene glycol (Carbowax, PEG 8000, Fisher Scientific Co., Fair Lawn, N.J. ) solution with a water potential of $1.1 \mathrm{MPa}$ (10.8 oz/32 fluid oz water) verified by osmometry (model 5500; Wescor Inc., Logan, Utah). Petri dishes were sealed with waxed film (Parafilm M, American National Can Co., Greenwich, Corm. ) to prevent evaporation and incubated in the dark at $68 \mathrm{~F}$ in a growth chamber for 7 days.

For matric priming, broccoli seeds were placed in 6.1-inch ${ }^{3}$ cylindrical glass jars containing vermiculite (horticultural grade, no. 2) in a ratio of 3.5 oz seed :2.8 oz vermiculite :27 fluid oz water and mixed thoroughly with a spatula. The seeds were added after the mixture had equilibrated for $24 \mathrm{~h}$. The jars were sealed with waxed film and incubated in darkness at $68 \mathrm{~F}$ for 7 days. Each day the jars were rotated one complete turn to ensure uniform mixing. The water potential of the vermiculite at the end of the experiment was $1.1 \mathrm{MPa}$ measured by psychrometry (model 83. J.R.D. Merrill Specialty Equipment, Logan, Utah).

After matric and osmotic priming, seeds were vigorously washed in tap water for $2 \mathrm{~min}$ and rinsed in 6.7 fluid $\mathrm{oz}$ of distilled water for $30 \mathrm{sec}$. The seeds were blotted dry to remove surface moisture, forced-air dried (95F) for 20 rein, and dried to a final moisture content of $5 \%$ to $6 \%$ over silica gel (45\% RH). Moisture content was expressed as a percentage of the seed dry weight after oven drying at $217 \mathrm{~F}$ for $17 \mathrm{~h}$ (ISTA, 1985). The seeds were dusted with thiram (tetramethylthiuram disulfide), sealed in plastic bottles, and stored at $-38 \mathrm{~F}$.

Field performance of primed and nonprimed seeds was evaluated in 1990, 1991, and 1992. In 1990, osmotically primed and nonprimed seeds were compared on a farm in Halifax County, Vs., in a Cecil clay loam (clayey, kaolinitic, thermic,Typic Hapludult). The soil was fertilized with 89N-38P-74K (lb/acre) before direct-seeding, and $50 \mathrm{~N} 45 \mathrm{P}-51 \mathrm{~K}$ was applied 6 weeks after planting ( O'Dell et al., 1992). In 1991 and 1992, the performances of matrically and osmotically primed seeds were compared to nonprimed seeds near Christiansburg, Vs., on a Groseclose clay loam (clayey, mixed, mesic, Typic Hapludult). In 1991 and 1992, the soil was fertilized with 99N45P-51K (lb/acre) before direct-seeding, and 50N45P-51Kwas applied 5 weeks after planting (O'Dell et al., 1992). The herbicide , $\alpha, \alpha, \alpha-$ trifluor-2, 6-dinitro-N,N-dipropyl-ptoludine (trifluralin, $25 \mathrm{fl}$. oz/ha) was double-disk-incorporated prior to seeding. Thermocouples measured soil temperature at seeding depth during emergence. Four replications of 100 seeds each were hand-sown on August 23, 15, and 16 in 1990, 1991, and 1992, respectively, 0.5 inch deep in twin rows $50 \mathrm{ft}$ long with a betweenrow spacing of 18 inches with guard rows planted on either side. Immedi ately after seeding, 0.75 inch of water was applied via an overhead irrigation system, and an additional 1 inch of water was applied weekly. Emergence was recorded at $12 \mathrm{~h}$ intervals when the hypocotyl hook first appeared above the soil. Disease and insect control measures were in accordance with local recommendations for broccoli (O’Dell et al., 1992). In 1990, heads were harvested throughout the season. In 1991, only $9 \%$ of the crop was harvested because of an early freeze. In 1992, entire plants were harvestedw hen the head diameter reached 5 inches. After harvest, the heads and 7.5 inches of stalk were cut and weighed separately from the remainder of the plant (U.S. Dept. of Agriculture, 1943).
The 1990 experiment was a randomized complete block design with two seed treatments. The 1991 and 1992 data were analyzed in the same ANOVA using a split-plot design with seed treatments assigned to subplots and years as main plots. Time values were log-transformed to produce lognormal distributions from positively skewed cumulative emergence and harvest time courses. Cumulative emergence and harvest data were plotted on a probit scale versus log time to produce straight lines with approximately equal slopes for each qeatment (Finney, 1971 ). Since the slope of probit plots is equal to $\sigma^{-1}$ (inverse of the standard deviation), it was possible to compare effects of priming on the uniformity of emergence and harvest. The log mean time to emergence (MTE) and mean time to harvest $(\mathrm{MTH})$ were determined graphically from the probit value of 0 or $50 \%$ emergence or harvest, ANOVA was performed using a personal computer program on log-time values and $\arcsin \sqrt{ } \%$ transformed percentage data,

\section{Results and discussion}

During seedling emergence in 1990 , the mean daily soil temperature was $82.2 \pm 1.4 \mathrm{~F}$, and the maximum daily soil temperatures exceeded $86 \mathrm{~F}$

Table 1. Field emergence and harvest data for matric- and osmotic-primed broccoli seeds.

\begin{tabular}{|c|c|c|c|c|c|c|}
\hline $\begin{array}{l}\text { Seed } \\
\text { treatment }\end{array}$ & $\begin{array}{c}\mathbf{M T E}^{\mathbf{z}} \\
\text { (d) }\end{array}$ & $\begin{array}{c}\sigma^{y} \text { of MTE } \\
\text { (d) }\end{array}$ & $\begin{array}{c}\text { Emergence } \\
(\%)\end{array}$ & $\begin{array}{c}\text { MTH }^{\mathbf{x}} \\
\text { (d) }\end{array}$ & $\begin{array}{c}\text { Harvest }^{\mathrm{w}} \\
(\%)\end{array}$ & $\begin{array}{c}\sigma \text { of MTH } \\
\text { (d) }\end{array}$ \\
\hline \multicolumn{7}{|c|}{1990} \\
\hline Osmotic primed & 8.5 & 1.8 & 43 & 86 & 46 & $N^{u}$ \\
\hline \multirow[t]{2}{*}{ Nonprimed } & 8.8 & 3.1 & 27 & 90 & 20 & NA \\
\hline & NS & * & NS & * & * & --- \\
\hline \multicolumn{7}{|c|}{$1991-92$} \\
\hline Matric primed & $5.2 \mathrm{a}^{\mathrm{v}}$ & 3.4 & $70 \mathrm{a}$ & $88^{t}$ & 48 & 1.6 \\
\hline Osmotic primed & $5.4 \mathrm{a}$ & 3.4 & $71 \mathrm{a}$ & 89 & 38 & 1.6 \\
\hline \multirow[t]{3}{*}{ Nonprimed } & $6.0 \mathrm{~b}$ & 2.9 & $66 \mathrm{~b}$ & 95 & 51 & 1.7 \\
\hline & * & NS & * & NS & NS & NS \\
\hline & & & 1991 & & & \\
\hline $\begin{array}{l}\text { Combined } \\
1992\end{array}$ & 5.7 & 4.0 & 64 & NA & $9^{t}$ & NA \\
\hline \multirow[t]{2}{*}{ Combined } & 5.4 & 2.6 & 74 & 89 & 38 & 1.6 \\
\hline & NS & $\star \star$ & ** & -- & $\star \star \star$ & $\cdots$ \\
\hline Year $\times$ treatment & NS & NS & NS & $\cdots$ & NS & $\cdots$ \\
\hline \multicolumn{7}{|c|}{$\begin{array}{l}\text { "Mean time to emergence. } \\
\text { "Standard deviation, } \\
{ }^{*} \text { Mean time to harvest. } \\
\text { "Percentage of heads harvested from seeds planted. All percentage data was arcsin transformed prior to } \\
\text { statistical analysis, and non-transformed values are displayed. } \\
\text { seans in columns within year groups are significantly different by } L S D^{005} \text { when separated by different } \\
\text { letters. } \\
{ }^{2} N A=\text { not available. } \\
\text { 'Data for } 1992 \text { only because frost ended the } 1991 \text { season with only } 9 \% \text { of the plants harvested. } \\
\text { NS, }{ }^{* * * * * * * N o n s i g i f i c a n t, ~ o r ~ s i g n i f i c a n t ~ b y ~ F ~ t e s t ~ a t ~} P=0.05,0.01,0.001, \text { respectively. }\end{array}$} \\
\hline
\end{tabular}


Table 2. Harvest results for plants grown from matric-and osmotic-primed broccoli seeds in 1992.

\begin{tabular}{lcccc}
\hline Treatment & $\begin{array}{c}\text { Head } \\
\text { fresh wt } \\
(\text { oz } / \text { head })\end{array}$ & $\begin{array}{c}\text { Plant } \\
\text { fresh wt } \\
(\text { oz/plant })\end{array}$ & $\begin{array}{c}\text { Marketable } \\
\text { heads } \\
(\%)^{z}\end{array}$ & $\begin{array}{c}\text { Total marketable } \\
\text { head yield } \\
(\mathrm{t} / \text { acre })\end{array}$ \\
\hline Matric primed & $5.7 \mathrm{a}^{\mathrm{y}}$ & $15.8 \mathrm{a}$ & 60.9 & 3.5 \\
Osmotic primed & $5.7 \mathrm{a}$ & $15.5 \mathrm{a}$ & 61.5 & 3.5 \\
Nonprimed & $6.3 \mathrm{~b}$ & $18.1 \mathrm{~b}$ & 53.0 & 3.0 \\
Significance & $* *$ & $* *$ & NS & NS \\
\hline
\end{tabular}

${ }^{2}$ Percentage data was arcsin transformed before statistical analysis, and non-transformed values are displayed.

"Means in columns separated by different letters are significantly different by $L S D_{0.05}$

${ }^{N S},{ }^{* *}$ Nonsignificant or significant by $F$ test at $P=0.01$, respectively.

on several days. The soil was severely crusted, but the MTE and final emergence were unaffected by priming in 1990 (Table 1). However, the standard deviation of MTE was less for osmotically primed seeds, indicating that primed seeds emerged more uniformly (Table 1). Osmotic priming failed to increase the percentage or uniformity of cabbage seed emergence at high temperatures (Perkins-Veazie et al., 1989). Osmotic priming decreased the time-spread of emergence of tomato, carrot, and onion seeds (Haigh et al., 1986). Extensive laboratory studies with tomato seeds showed that germination rate is increased by priming, while germination uniformity remains constant (Dahal et al., 1990). The greater uniformity of emergence of primed broccoli seeds in 1990 may be due to faster germination that reduced seedling exposure to high temperatures, crusting, and other stresses that prolong field emergence.

Conditions were more conducive to uniform stand establishment in 1991 and 1992. Mean soil temperatures during emergence were $75 \pm 0.9$ and $75 \pm$ 2.8F in 1991 and 1992, respectively, and soil crusting was less severe than in 1990. Primed seeds had about $15 \mathrm{~h}$ lower MTE than nonprimed seeds, and there was no difference in MTE or final emergence percentage between matric- and osmotic-primed seeds (Table 1). Laboratory studies have shown that for many vegetable species matric-primed seeds germinate faster than osmotic-primed seeds (Khan, 1992). However, differences in MTE between priming treatments were not detectable in our field study. There were no differences in the standard deviation of emergence among seed treatments, although emergence was more variable in 1991 than in 1992 (Table 1). The final emergence percentage was $5 \%$ greater for primed seeds than for nonprimed seeds in 1991 and 1992. The final emergence percentage for all treatments in 1992 was $10 \%$ greater than in 1991 (Table 1 ). In contrast, priming didnot decrease MTE or improve percent emergence in 1990, demonstrating that the performance of primed seeds is variable and depends on several interacting factors such as the seed species, the seed lot, soil type, soil temperature, and water (Table 1).

In all 3 years, the MTE of primed seeds was never more than $15 \mathrm{~h}$ earlier than nonprimed seeds. While this difference may help seedlings escape environmental stresses that reduce stands, it is unlikely that such a small interval would result in an earlier harvest. However, plants from primed seeds matured heads at least 4 days earlier in all experiments (Table 1). The earlier maturity most likely resulted from differences in plant population density that affected the rate of crop development and was not directly caused by earlier emergence or faster growth by primed seedlings. For example, in 1990 nonprimed seedlings emerged irregularly in clumps resulting in greater inter-plant competition and slower development compared to primed seeds which emerged uniformly at a spacing that did not inhibit development (Table 1 ). The higher percentage of heads harvested in 1990, resulted directly from the greater emergence of primed seeds (Table 1).

In 1991 and 1992, the use of primed seeds did not result in an earlier harvest, increase the percentage of plants harvested, or change the uniformity of MTH (Table 1). Nonprimed seeds had a lower percent emergence, but in contrast to the 1990 experiment, emergence was more uniform (Table 1). Plants and heads were larger because of reduced inter-plant competition that occurred in primed seed plots (Table 2). Osmotic priming reduced the MTE of cabbage and Brussels sprouts seeds by 2 to 4 days and increased total plant fresh weight at harvest (Khan et al., 1980/81). In our study, priming did not increase marketable yield. The larger heads from nonprimed seeds compensated for the higher plant population densities from primed seeds resulting in similar total yields (Table 2).

Earlier crop maturity from primed seeds has been reported in crops that are harvested for vegetative tissues such as carrots (Brocklehurst and Dearman, 1983; Szafirowska et al., 1981), onions (Brocklehurst and Dearman, 1983), and lettuce (Gray and Steckel, 1976). These crops mature rapidly, are uniformly planted in block configuration, and are harvested individually, so changes in plant spacing affect plant size and maturation rate. Since delayed emergence or missing plants reduce yield and inhibit uniform development, factors, such as priming, that reduce the MTE and increase percent emergence dramatically alter the rate of crop development by affecting inter-plant competition. The earlier harvest of plants grown from primed seeds has been attributed to more uniform establishment and reduced plant-toplant competition in other species as well (Tekrony and Egli, 1991).

The advantages of earlier emergence are less likely to translate into earlier harvest in crops that produce fruit. Alvarado et al. (1987) determined that 4 days earlier emergence of primed tomato seeds was maintained through early leaf development but was eventually lost later in the growth cycle, probably during pollination, so that priming did not increase the earliness of harvest for processing tomatoes. In another study with processing tomatoes, priming increased the percentage of red fruit at harvest by 10 to 12\% (Wolfe and Sims, 1982). Primed watermelon seeds emerged more rapidly but generally did not produce greater early or total yield (Elmstrom, 1985 ). The correlation of area yield and seed vigor is low in crops such as tomato that produce fruit (Tekrony and Egli, 1991).

Priming decreased the MTE by only a few hours under soil and temperature conditions conducive to broccoli seed germination and had little effect on the time to emergence under high temperature and crusting condi- 
tions (Table 1). However, the few hours gained in emergence may be critical in reducing exposure to stresses that may decrease emergence. The earlier harvests and higher yields from primed seeds apparently resulted from alteredplant population densities which affected plant-to-plant competition. Since the use of primed seeds consistently. improved emergence under a variety of soil and temperature conditions, the added cost of primed broccoli seeds may be worth the investment for many growers in the southeastern United States.

\section{Literature Cited}

Alvarado, A.D., K.J. Bradford, and J.D. Hewitt. 1987. Osmotic priming of tomato seeds: effects on germination, field emergence, seedling growth, and fruit yield. J. Amer. Soc. Hort. Sci. 112:427432.

Bradford, K.J. 1986. Manipulation of seed water relations via osmotic priming to improve germination under stress conditions. HortScience 21:1105-1 112.

Brocklehurst, P.A. and J. Dearman. 1983. Interactions between seed priming treatments and nine seed lots of carrot, celery, and onion: II. Seedling emergence and plant growth. Ann. Applied Biol. 102:585593.

Cantliffe, D.J., J.M. Fisher, and T.A. Nell. 1984. Mechanism of seed priming in circumventing thermodormancy in lettuce. Plant Phys. 75:290-294.

Copeland, L.O. and M.B. McDonald. 1985. Principles of seed science and technology. 2nd ed. Macmillan, New York. p. 280281 .

Dabal, P.K., J. Bradford, and R.A. Jones. 1990. Effects of priming and endosperm integrity on seed germination rates of tomato genotypes: I. Germination at suboptimal temperature. J. Expt. Bet. 41:14311439.

Elmstrom, G. W. 1985. Influence of seed priming and row covers on early maturity of watermelon. Proc. Fla. State Hort. Soc. 98:281-284.

Elson, M. K., R.D. Morse, D.D. Wolf, and D.H. Vaughn. 1992. High temperature inhibition of seed germination and seedling emergence of broccoli. HortTechnology 2:417-419.

Finney, D.J. 1971. Probit analysis. 3rd ed. Cambridge Univ. Press, Cambridge.

Gray, D. and J.R.A. Steckel. 1976. The effects of pre-sowing seed treatments on the germination and emergence of lettuce seeds at high salt concentrations. Scientia Hort. 5:1-9.

Haigh, A.M., E.W.R. Barlow, F.L. Milthorpe, and P.J. Sinclair. 1986. Field emergence of tomato, carrot, and onion seeds primed in an aerated salt solution. J. Amer. Soc. Hort. Sci. 111:660-665.

International Seed Testing Association. 1985. International rules for seed testing. Seed Sci. Technol. 4:1-177.

Jett, L. W. and G.E. Welbaum. 1992. Osmotic and solid phase priming of broccoli seed, p. 73-81. In: Proc. Natl. Symp. Stand Establishment Hort. Crops, Ft. Myers, Fla.

Khan, A.A. 1992. Preplant physiological seed conditioning. Hort. Rev. 14:131181.

Khan, A.A., J.D. Maguire, G.S. Abawi, and S. Ilyas. 1992. Matriconditioning of vegetable seeds to improve stand establishment in early field plantings. J. Amer. Soc. Hort. Sci. 117:41-47.

Khan, A.A., N.H. Peck, and C. Samimy. 1980-81. Seed osmoconditioning: physiological and biochemical changes. Isr. J. Bet. 29:133-144.

O'Dell, C. R., R.D. Morse, P. Ramsey, and A. Borowski. 1992. Fall broccoli production- a guide for southside Virginia farmers. Va. Coop. Ext. Serv. Publ. 438-011.

Perkins- Veazie, P.M., D.J. Cantliffe, and J.M. White. 1989. Improved stand establishment of Direct-seeded cabbage with seed covers. J. Amer. Soc. Hort. Sci. 114:36-39.

Szafirowska, A., A.A. Khan, and N.H. Peck. 1981. Osmoconditioning of carrot seeds to improve seedling establishment and yield in cold soil. Agron. J. 73:845848 .

Tekrony, D. and K. Egli. 1991. Review of seed vigor and crop yield. Crop Sci. 31:816822 .

U.S. Department of Agriculture. 1943. United States standards for broccoli. U.S. Dept. Agr., Agr. Mktg. Serv., Washington, D.C.

Wolfe, D. W. and W.L. Sims. 1982. Effects of osmoconditioning and fluid drilling of tomato seed on emergence rate and final yield. HortScience 17:936-937.

Wurr, D.C.E. and J.R. Fellows. 1984. The effect of grading and priming seeds of crisp lettuce cv. Saladin, on germination at high temperature, seed vigour, and crop uniformity. Ann. Applied Biol. 105:345-352. 